\title{
Pårørende bør være til stede under hjerte-lunge-redning
}

\section{Ved å spørre pårørende om de ønsker å være til stede under hjerte- lunge-redning ved hjertestans kan risikoen for posttraumatisk stress- syndrom reduseres.}

I en fransk studie om prehospital hjertelunge-redning har man studert pårørendes reaksjoner etter at deres nærmeste er forsøkt reddet etter hjertestans (1). Av 15 ambulansestasjoner ble åtte trukket ut til systematisk å spørre pårørende om de ønsket å være til

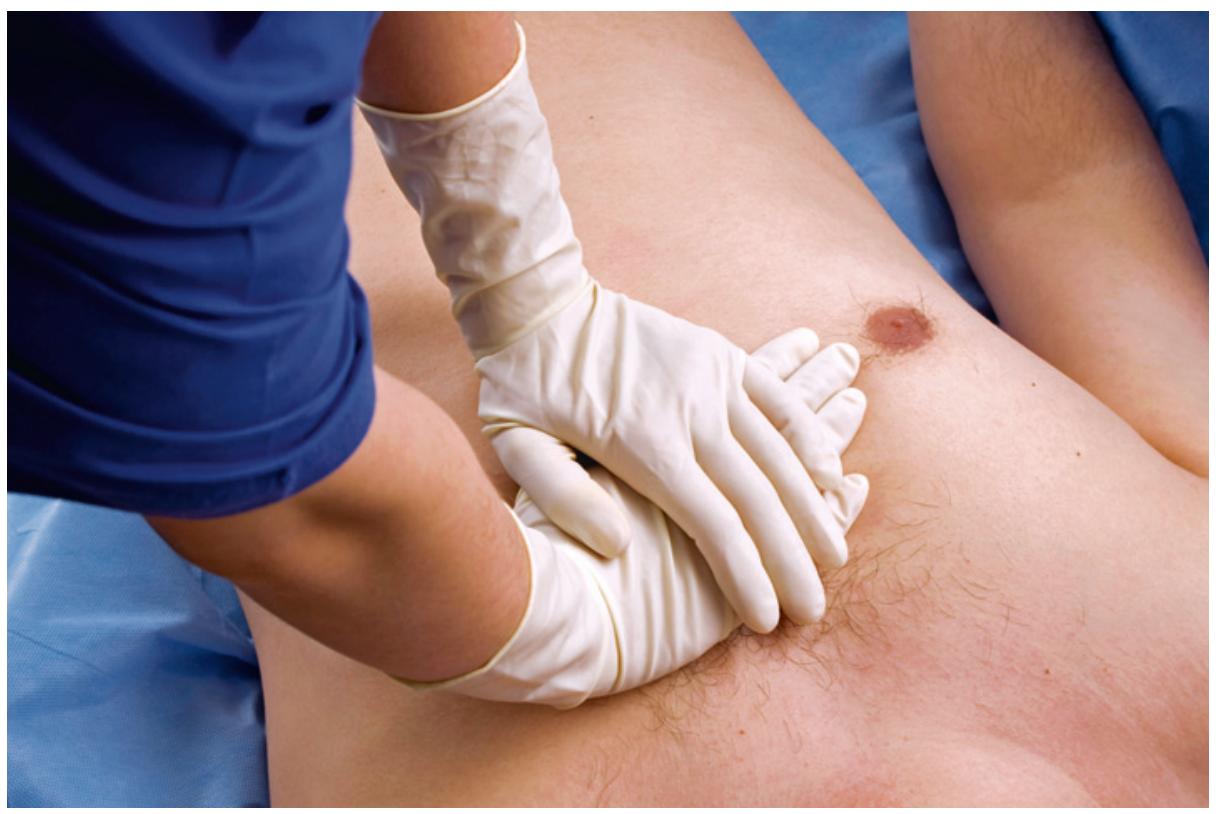

Illustrasjonsfoto Istockphoto stede ved hjerte-lunge-redningen. I intervensjonsgruppen var $79 \%$ av de pårørende til stede, mot $43 \%$ i kontrollgruppen. Totalt 570 pårørende ble inkludert. De ble telefonintervjuet tre måneder etter hendelsen og spurt om symptomer på posttraumatisk

stress-syndrom (PTSD). Forekomsten var da signifikant høyere i kontrollgruppen (justert oddsratio 1,$7 ; 95 \% \mathrm{KI}$ 1,2-2,5).

- Dette er en god og stor studie som støtter at det normalt ikke er noen grunn til å skåne pårørende fra å være til stede under hjertelunge-redning, sier avdelingssjef Pål Klepstad ved Intensivavdelingen, St. Olavs hospital. Han har også erfaring fra luftambulansetjeneste. - Tvert imot kan det å ha vært til stede føles bedre. Det kan bidra til at de vet at helsepersonellet gjorde en best mulig innsats under forsøket på gjenoppliving, sier han.

I studien hadde de som ikke bevitnet hjertelunge-redningen, oftere symptomer på angst og depresjon. At pårørende var til stede påvirket ikke gangen i gjenopplivingen, overlevelsen, emosjonelt stress blant behandlerne eller antallet pasientklager.

- Et gammelt argument mot å ha pårørende til stede er at det reduserer helsepersonellets prestasjoner. Spissformulert kan man si at hvis man ikke føler seg vel med pårørende til stede under hjerte-lunge-redningen, er man bedre tjent med å oppøve sin egen trygghetsfølelse enn å fjerne dem som står den syke nær, sier Klepstad.

\section{Ole Kristian Losvik \\ losvik@gmail.com \\ Klinikk for hjertemedisin \\ St. Olavs hospital \\ Litteratur \\ 1. Jabre P, Belpomme V, Azoulay E et al. Family presence during cardiopulmonary resuscitation. N Engl J Med 2013; 368: 1008-18}

\section{T-celler beskytter kreftceller}

\section{Immunsystemet forsøker å be- kjempe kreftsvulster, men kan også bidra til å beskytte dem.}

Regulatoriske T-celler, en celletype som blokkerer autoimmune responser, er ofte anriket $\mathrm{i}$ kreftsvulster. Det antas at slike celler også forhindrer immunresponser rettet mot tumoren. Ved mange kreftformer er et høyt antall slike celler assosiert med dårlig prognose. Det har vært uklart hvordan disse cellene utvikles og hva slags antigener de gjenkjenner. Amerikanske forskere har nå studert utviklingen av regulatoriske T-celler i en musemodell som utvikler prostatakreft (1).

Forskerne påviste antigensspesifikke regu- latoriske T-celler som var anriket i tumoren. Disse cellene var imidlertid ikke reaktive overfor et tumorspesifikt antigen som kun uttrykkes i kreftcellene. De regulatoriske Tcellene gjenkjente derimot et prostataassosiert antigen som også finnes i friskt vev.

- Studien viser at tumorinfiltrerende regulatoriske T-celler utvikles på vanlig måte $i$ thymus, sier forsker Ludvig A. Munthe ved Senter for immunregulering, Oslo universitetssykehus. - Det har vært spekulert om kreftceller kan forhindre immunovervåking ved å utskille cytokiner som konverterer Tceller i kreftvevet til regulatoriske T-celler. Men denne studien viser at kroppens normale regulatoriske T-celler også beskytter kreftceller fra immunresponser, sier han.
- Regulatoriske T-celler mister sin immunhemmende virkning ved inflammasjon. Det er derfor viktig å etablere et inflammatorisk miljø i tumorvevet dersom immunsystemet skal ha mulighet til å forkaste en kreftsvulst. En ny gruppe legemidler, bl.a. ipilimumab, har en slik proinflammatorisk T-cellestimulerende virkning, sier Munthe.

\section{Trine B. Haugen \\ trine.b.haugen@hioa.no \\ Tidsskriftet}

\section{Litteratur}

1. Malchow S, Leventhal DS, Nishi S et al. Airedependent thymic development of tumor-associated regulatory T cells. Science 2013; 339: 1219-24. 